Royal Eye Hospital with Brudenell Carter. Much of his spare time time in early years was spent at the Zoo where he studied the com? parative anatomy of the eye. Papers on the mammalian eyes appeared in the Phil. Trans: Roy. Soc. Lond. in 1901, and on reptilian and amphibian eyes in 1924. He was a pioneer in colour photography and maintained his interest in photography to the end of his life.

Johnson left England for South Africa in 1911 and practised for a. time in Johannesburg. He was a good linguist and an extremely versatile man. In,later years he took great interest in spiritualism and devoted much of his time to devising optical instruments and photographic experiments. He wrote a good deal. . Besides those Royal Society papers already mentioned, his best known ophthalmic book was a very convenient pocket atlas of the fundus in which he had the advantage of Mr. Head's collaboration in the illustrations. This book went to a second edition.

\title{
NORMAN HOWARD PIKE
}

Norman Howard Pike, of 6, Charlton Park Gate, Cheltenham, died after a short illness on March 12, at the age of 71. He was one of a family of eleven and was educated at Dulwich College. At Guy's he was contemporary with a galaxy of talen't, obtäined Honours in medicine and obstetrics in the London M.B., B.S., and in 1896 was appointed Resident Obstetrical Assistant. The following year he acted as House Physician to Dr. Hale White.

$\mathrm{He}$ worked in general practice at Heckmondwike (Yorks.) for ten years before specializing in ophthalmology and oto-laryngology. It was in 1907 that he left his practice and, accompanied by his wife and children, went to study in Vienna. It is greatly to his credit that during this period of tuition there, he contrived a useful piece of clinical research, the results of which appeared in the November and December numbers of the Journal of Laryngology, Rhinology and Otology in 1908 under the title "An Examination into the Condition of the Vestibular Apparatus in a Series of Cases of Deafness of Non-suppurative Origin." "Thirty-eight of the seventy-four cases reported on he investigated himself whilst working in Professor Urbantschitsch's clinic. The remainder he owed to the collaboration. of Dr. Bárány. An important and interesting point which emerged was the constant finding of diminution or absence of vestibular irritability in cases of deaf congenital syphilitics. On his return to England, he worked as a Clinical Assistant at Moorfields and as a House Surgeon at the Royal Ear Hospital, Soho, prior to his appointment in 1909 as Surgeon to the Eye, Ear, Nose and Throat Hospital at Cheltenham, before its amalgamation with the General Hospital. Until his retirement in 1932 under the age limit regulations he served the hospital efficiently 
and conscientiously and he continued in practice until a short time before his death, retaining his vigour and enthusiasm to a remarkable degree. He was a member, also, of the Consulting Staffs of the Herefordshire General Hospital and the Cheltenham Children's Hospital. - .

For many years Pike attended regularly the meetings of the Midland Ophthalmological Society and was President of the Society in 1931-2. He read a useful and typically practical paper to this Society in 1931 on accommodation and convergence, whilst at the yearly congress at Oxford he was familiar to many and a member of council.

Pike's most conspicuous characteristics were his integrity and honesty. The combination of these characteristics with ability, patience, kindliness and sound knowledge made him a first-class consultant, and he was consequently greatly respected and trusted by his fellow practitioners and patients. In his later years his enthusiasm and keenness were hardly diminished and he made every effort to keep abreast with advances in his specialities. Physically, too, he was a. man of vigour. A good cricketer and 'rugger player in his' youth, he later became a keen golfer and each week-end would find him on those magnificent links on Cleeve Hill, near which he had a cottage.

He leaves a widow, two sons and two daughters. His second son is a Commander in the Royal Navy.

\section{NOTES}

Presentation

THE Association for the Prevention of Blindness has made a presentation to Mr. A. F. MacCallan, C.B.E., of a Research microscope, on permanent loan, in recognition of his work on conjunctival diseases, especially trachoma.

Royal Eye Hospital : Clinical Society

A MeEting of the Society will be held on July 28, at 5.30 p.m. Dr. D. C. Ardley will speak on sulphonamide therapy.

Oxford Ophthalmo. logical Congress
THE meeting of the Congress in July has been cancelled. It is hoped to hold the Congress later in the year and if this can be arranged a circular will be sent to members announcing the date.

Special Notice

WE are asked by the Ministry of Information to state that the fact that goods made of raw materials in short supply owing to war conditions are advertised in this journal should not be taken as an indication that they are necessarily available for export. 